\title{
IAMJ
}

INTERNATIONAL

AYURVEDIC

MEDICAL JOURNAL

\section{AYURVEDIC MANAGEMENT OF ANKYLOSING SPONDYLITIS (ASTHIMAJJAGATA VATA) - A CASE STUDY}

\author{
Vaishnavi Sunil Deo \\ $3^{\text {rd }}$ Year PG Scholar Panchakarma \\ Tilak Ayurved Mahavidyalaya, Pune \\ Dr. Anjali Damle, Assistant Professor, Tilak Ayurved Mahavidyalaya, Pune, Maharashtra, India
}

Corresponding Author: vaishnavideo30@gmail.com

\section{https://doi.org/10.46607/iamj2709062021}

(Published Online: June 2021)

Open Access

(C) International Ayurvedic Medical Journal, India 2021

Article Received: 02/06/2021 - Peer Reviewed: 09/06/2021 - Accepted for Publication: 10/06/2021

\section{Check for updates}

\begin{abstract}
Ankylosing Spondylitis is a type of arthritis that mostly affects spine and has a strong association with genetic marker HLAB27. The etiology of this disease is not much clear, but the pathogenesis can be ruled out to be immune mediated. Late adolescence or early adulthood is the prime age for the onset with symptoms ranging from dull pain with mild stiffness and reaching up to totally fused spine and severe hip joint arthritis. It has been seen that the patients diagnosed with ankylosing spondylitis show a variety of symptoms which can be categorized according to Ayurveda under aamavata, vatarakta, sandhigatavata samavastha or asthimajjagata vata. Here in this case study the symptoms of the patients were much like asthimajjagata vata and the dosha dushti was lina up to asthi and majja dhatu, hence both shamana and panchakarma chikitsa by the means of basti was planned.
\end{abstract}

Keywords: Ankylosing Spondylitis, Arthritis, Asthimajjagata vata, Basti.

\section{INTRODUCTION}

In today's era, our society is surrounded by numerous types of diseases which hampers one's lifestyle in one or the other way. Ankylosing Spondylitis is one such disease responsible for hampering human lifestyle up to a large extent as it an inflammatory condition having joint pain, stiffness and a loss of mobility in the spine and lower back. The pain usually starts in the lower back and can spread up to neck or damage joints in other parts of the body. It affects men more than women (near about ratio $3: 1$ ) and the onset is 
insidious, progressively capturing the spine especially sacroiliac joint. In modern science the disease is managed with NSAIDs, steroids and biologics and rehabilitated with physiotherapy. The range of action of this line of treatment is seen to be limited and with low beneficiary effects. Thus, the role of Ayurveda stands important here as it can treat such patients in accordance with Asthimajjagata vata. As cited by Charakacharya in $28^{\text {th }}$ chapter of chikitsa sthan, it is characterized as

- Bhedo asthiparvanam (sharp, stabbing pain in bones and joints),

- Sandhishoola (joint pain),

- Mamsabalakshyaya (muscle and body weakness),

- Aswapna (sleeplessness) and

- Santatam ruka (continuous severe pain) which can be corelated with the symptoms of ankylosing spondylitis in many patients.

\section{Case Study}

Chief complaints- A 30yr old male patient came with the symptoms of pain in B/L hip joint, right shoulder along with whole spine (back pain) and neck with mild stiffness and restriction in movement -for 12 years.

$\mathrm{H} / \mathrm{o}$ present illness- The onset of the disease was with dull pain in lower back region which was radiating to thighs- in the year 2008. Patient took temporary pain killers and had symptomatic relief for a period. In the year 2010 patient was tested HLAB27 positive and had aggravated above set of symptoms. Patient was prescribed with steroids and pain killers according to the severity of pain. Physiotherapy and steroids gave temporary relief hence the patient came to seek ayurvedic treatment.

\section{Etiology and its Ayurvedic aspect-}

- Prakruti-Vata pradhan pittanubandhi

- Ahara- Katu ras dominant, cheese, butter, paneer, frozen food, bread (ruksha aahar).

- Vihara- IT job (continuous sitting job for 7-8 hours), lived in abroad (cold weather in dominance) for 5-6 years, frequent trekking, 2-3 hrs of gym daily

- Manasik-Mental traits like chinta in prevalence.

- Vyasana-Tea or coffee 2-3 times a day

As Charakacharya has mentioned in Strotoviman adhyaya, ati vyayam, vatakar aahar-vihar, viruddhahar are the contributing factors for asthi and majja vaha strotas dushti.

\section{Laboratory Investigations-}

1. HLAB27- positive

2. C-reactive protein $-142.9 \mathrm{mg} / \mathrm{L}$

3. Erythrocyte sedimentation rate (ESR)- $30 \mathrm{~mm} / \mathrm{hr}$

- MRI Both Hip Joints with Contrast19/06/2010: $\mathrm{B} / \mathrm{L}$ inflammatory synovitis with effusion and marrow oedema.

- X-Ray Pelvis with Both Hip Joints (A.P. View)- 06/11/2017: Features suggestive of secondary osteoarthritis more on left side - chronic inflammatory arthritis.

- X-Ray Pelvis with Both Hip Joints (A.P. View)- 24/08/2020 Periarticular mild sclerosis at $\mathrm{B} / \mathrm{L}$ SI is noted in present radiograph with degenerative changes in left hip joint has marginally increased in form of irregular articular surface.

\section{Samprapti Ghataka-}

Nidan-Vatakar aahar vihar, Dosha-Vata, DushyaRakta, asthi, majja, snayu, Strotas- Asthi, majja Rogamarga-Madhyama, Udhbhavstan-Pakvashaya, Kati sandhi, Vyaktasthan-Vankshan sandhi, Kati, asthi, Roga swabhava- Chirakari

\section{Material and methods (Treatment plan)-}

- According to Ayurveda, vayu is the main constituent of the body which initiates and maintains all bodily functions in its natural way. When this vayu gets vitiated, it hampers its own pathway and lodges itself into any frail part of the body causing the disease. Here the vayu lodges itself into asthi and majja dhatu causing its prakopa and dhatu's kshaya. Hence according to Acharya Charaka, 'bahya-abhyantar sneha' is the line of treatment for asthimajjagata vata which was carried out in this case.

- Firstly, we went for pachana treatment (aushadhi and pathyapathya) but the main focus was on vyadhi pratenik chikitsa and hence a blend of above two treatment modalities was planned. Along with that bahya karma chikitsa in the form of snehana (abhyanga) and swedana (bashpa and pinda sweda) was started for vata shamana, snehana and bala vardhana.

- Basti - the first and foremost chikitsa for vata was planned by examining vyadhi swarup, avastha, rugna bala, agni and kala. It not only 
pacifies vitiated vata but also strengthens the dhatus by its snehana karma. In this case of asthimajjagata vata, anuvasa basti was preferred as it a snehik basti which by its virtue of sukhma guna can reach upto asthi-majja dhatu and its snigdha and ushna guna helps to pacify the vitiated vata. Thus, the karma of sneha which is'sneho anilam hanti, mrudu karoti deham' can be utilized to treat this disease.

- When the samyak snigdha lakshanas and vyadhi lakshanopasham was observed, basti treatment was stopped and patient was prescribed with shamana chikitsa for shesh dosha shaman and rasayan karma to maintain body's equilibrium.

\section{Pachana and vyadhi pratyanik chikitsa -}

\section{Abhyantar chikitsa-}

- Cap. Ksheerguduchi 2capsules + samshamani vati $1 \mathrm{tab}+$ ashwagandha choorna $250 \mathrm{mg}$ twice a day.
- Drakshasava special $20 \mathrm{ml}$ with water vyanodana kali.

\section{Bahya karmopachar -}

- Sarvanga abhyanga-Mahanarayana tail

- Sarvanga swedana-Bashpa sweda with dashamoola kwath

- Sthanik pinda sweda- Deodara+ashwagandha+vidari siddha ksheer odana pottali

2. Panchakarmopachara (Anuvasana Basti)-

- Mahanarayan tail $40 \mathrm{ml}+$ Sukumara ghrita $20 \mathrm{ml}$ (matra was increased gradually according to the sneha jarankala and agni bala)

\section{Shamana chikitsa-}

- Cap. Ksheerguduchi 2capsules + samshamani vati $1 \mathrm{tab}+$ ashwagandha choorna 250mg + chopchinnyadi choorna $500 \mathrm{mg}$ with warm water twice a day.

\section{Assessment Criteria-}

The following are the subjective and objective criteria for assessing the effect of treatment.

\section{Subjective parameters-}

1.Sandhisthabdhata (Joint stiffness)

\begin{tabular}{|l|l|}
\hline Grade & Severity \\
\hline 0 & No stiffness \\
\hline 1 & 5 mins to 2 hours \\
\hline 2 & 2 hours to 8 hours \\
\hline 3 & More than 8 hours \\
\hline
\end{tabular}

2. Sandhishoola (Joint pain)

\begin{tabular}{|l|l|}
\hline Grade & Severity \\
\hline 0 & No pain \\
\hline 1 & Slight pain \\
\hline 2 & Moderate pain \\
\hline 3 & Severe pain \\
\hline
\end{tabular}

3. Balakshaya (weakness)

\begin{tabular}{|l|l|}
\hline Grade & Severity \\
\hline 0 & No weakness \\
\hline 1 & Feels weakness occasionally \\
\hline 2 & Feels weakness after activity or heavy work only \\
\hline 3 & Feels weakness after little work or activity also \\
\hline
\end{tabular}




\section{Objective Parameters-}

1. C-reactive protein

2. Erythrocyte sedimentation rate (ESR)

\section{OBSERVATION AND RESULT-}

\section{Subjective Criteria}

\begin{tabular}{|l|l|l|}
\hline Subjective parameters & Before & After \\
\hline Sandhisthabdhata (Joint stiffness) & 1 & 0 \\
\hline Sandhishoola (Joint pain) & 3 & 1 \\
\hline Balakshaya (weakness) & 2 & 0 \\
\hline
\end{tabular}

\section{Objective Criteria}

\begin{tabular}{|l|c|c|}
\hline Objective parameters & Before & After \\
\hline C- reactive protein & $142.9 \mathrm{mg} / \mathrm{L}$ & $3.66 \mathrm{mg} / \mathrm{L}$ \\
\hline Erythrocyte sedimentation rate & $30 \mathrm{~mm} / \mathrm{hr}$ & $8 \mathrm{~mm} / \mathrm{hr}$ \\
\hline
\end{tabular}

After 3 months of karma and shamana chikitsa the above result was seen. Patient got a significant relief and had gradually stopped allopathic medicines.

\section{DISCUSSION}

Vata when lodges itself into deep seated dhatus (gata vata) like asthi and majja manifests itself into a kashta sadhya vyadhi. The line of treatment in this case study was planned accordingly by administration of sneha orally and by the means of Basti. Capsule ksheerguduchi was administered since day one to strengthen asthi-majja dhatu by snehana and also for vata shamana. Ashwagandha having the vata shamak and mamsa balya properties was also given. Drakshasava, an excellent agnidipaka helps to maintain agni and stimulates other aushadhi dravyas to act with their full potency. Abhyanga, bashpa and sthanik pinda sweda were performed for pacifying vata and dhatu bala vardhan. As the samprapti was deep up to asthi majja dhatu with vata being the chief vitiated dosha, only snehana was required and hence yamak sneha was preferred (mahanarayan tail + sukumar ghrita). In $37^{\text {th }}$ chapter of chikitsa sthan of Sushruta Samhita it has been indicated to administer in all 18 basti for its potency to reach up to shukra dhatu, hence the patient was given 18 anuvasan basti along with two erandamuladi madhutailik niruha basti in the middle for dosha anuloman.

\section{CONCLUSION}

In modern medical science ankylosing spondylitis has a limited scope for treatment. The symptoms can be corelated with asthimajjagata vata up to a large extent and hence it's effective management can be done as per the chikitsa indicated in our texts. Thus, the above case study can be a documented evidence for effective management of ankylosing spondylitis (asthimajjagata vata) through basti and shaman aushadhi chikitsa.

\section{REFERENCES}

1. Prof. Ravidatta Tripathi, Charaka Samhita Chikitsasthan, chapter28, shloka33, Chaukhamba Sanskrit Pratishthan Delhi: 2009 P 693

2. Prof. Ravidatta Tripathi, Charaka Samhita Chikitsasthan, chapter28, shloka93, Chaukhamba Sanskrit Pratishthan Delhi: 2009 P 704

3. Kaviraj Atridev Gupta, Ashtang Hridayam Nidana sthan, chapter15, shloka12, Chaukhamba prakashan Varanasi: 2017 P 376

4. Prof. Ravidatta Tripathi, Charaka Samhita Siddhisthan, chapter01, shloka7, Chaukhamba Sanskrit Pratishthan Delhi: 2009 P 876

5. Kaviraj Ambikadatta Shashtri, Sushrut Samhita Chikitsasthan, chapter37, shloka70-74, Chaukhamba Sanskrit Sansthan Varanasi: 2020 P202-203

\section{Source of Support: Nil Conflict of Interest: None Declared}

How to cite this URL: Vaishnavi Sunil Deo: Ayurvedic Management Of Ankylosing Spondylitis (Asthimaj-Jagata Vata) - A Case Study. International Ayurvedic Medical Journal \{online\} 2021 cited June, 2021\} Available from: http://www.iamj.in/posts/images/upload/1312_1315.pdf 